\title{
ACUTE COMPLICATIONS IN MULTIPLE MYELOMA
}

\author{
Stankovikj Svetlana, ${ }^{1}$ Martinova Kata ${ }^{2}$ \\ ${ }^{1}$ University Clinic of Hematology, Skopje, Macedonia \\ ${ }^{2}$ University Childrenžs Hospital, Skopje, Macedonia
}

Primljen/Received 03. 04. 2017. god.

Abstract: Multiple myeloma is a malignant disorder of plasma cells, characterized by uncontrolled and progressive proliferation of a single clone of plasma cells. The disease leads to progressive morbidity and eventual mortality by lowering resistance to infection and causing significant skeletal destruction with bone pain, pathological fractures and hypercalcemia. Improved understanding of the multiple myeloma biology along with the discovery of novel anti-myeloma agents has led to a better-quality treatment of these patients. However, it still remains an incurable disease for the vast majority of patients, with a median survival 2-3 years. Patients with multiple myeloma frequently develop complications that are reason for early mortality within 60 days of diagnosis. Acute complications such as hyperviscosity syndrome, hypercalcemia, spinal cord compression, early infection, bone disease and renal impairment may be life-threatening. The treatment of these medical emergencies has greatly decreased morbidity and early mortality in patients.

Key words: multiple myeloma, hyperviscosity syndrome, hypercalcemia, spinal cord compression.

\section{INTRODUCTION}

Multiple myeloma (MM) is a malignant disorder of plasma cells, characterized by uncontrolled and progressive proliferation of a single clone of plasma cells. The disease leads to progressive morbidity and eventual mortality by lowering resistance to infection and causing significant skeletal destruction with bone pain, pathological fractures and hypercalcemia (1). At the time of diagnosis, $\mathrm{MM}$ is a heterogeneous disease, with a course that varies on the basis of both disease and host-related factors (age, renal function, stage, chromosomal abnormalities etc.). Multiple myeloma causes significant morbidity and mortality. It accounts for approximately $1 \%$ of all malignancies and $13 \%$ of hematological cancers. Approximately 50000 patients per
Prihvaćen/Accepted 23. 06. 2017. god.

year are diagnosed with MM in EU and US, and 30000 patients per year die due to multiple myeloma (2).

MM can cause many acute complications such as hyperviscosity syndrome, hypercalcemia, spinal cord compression, early infection, bone disease and renal impairment; some of them are life-threatening. The treatment of these medical emergencies has greatly decreased morbidity and early mortality in patients.

\section{Hyperviscosity syndrome}

Hyperviscosity syndrome occurs in cases with high serum paraprotein levels; monoclonal hypergammaglobulinemia is the most common cause, particularly those of IgA or IgG3 type. The reasons for elevated viscosity are increased protein content and large molecular size, abnormal polymerization, and abnormal shape of immunoglobulin molecules (3). Symptomatic hyperviscosity is much more common in Waldenstrom's macroglobulinemia (10-30\%) than it is in myeloma (2-6\%). Symptoms of hyperviscosity usually appear when the normal serum viscosity of 1.4 to 1.8 cp reaches 4 to $5 \mathrm{cp}$, corresponding to a serum immunoglobulin $\mathrm{M}$ (IgM) level of at least $3 \mathrm{~g} / \mathrm{dL}$, an IgG level of $4 \mathrm{~g} / \mathrm{dL}$, and an IgA level of $6 \mathrm{~g} / \mathrm{dL}$. Symptoms include bleeding and ocular, neurological and cardiovascular manifestations (mucosal bleeding, blurred vision, headaches, and dyspnea). Immediate therapy of symptomatic hyperviscosity is directed at reduction of blood viscosity by plasmapheresis to control symptoms. Long-term management is directed at control of the underlying disease to prevent production of the monoclonal protein (4).

\section{Hypercalcemia}

Patients with multiple myeloma are commonly diagnosed with hypercalcemia. In fact, hypercalcemia is one of the four diagnostic "CRAB" criteria (calcium ele- 
vation, renal insufficiency, anemia and bone disease) used to distinguish smoldering myeloma and monoclonal gammapathies of undetermined significance from active, symptomatic multiple myeloma. About 10 to $15 \%$ of patients with multiple myeloma present with hypercalcemia at the time of initial diagnosis, while more than $25 \%$ will be found to have hypercalcemia at some point during the trajectory of their disease, usually at the time of disease progression and relapse $(5,6)$. Hypercalcemia related to multiple myeloma is caused by the breakdown of bone which leads to the release of calcium into the blood (7). This can be a serious problem if appropriate treatment is not given immediately. Symptoms associated with hypercalcemia may be subtle or dramatic, and can include: nausea and vomiting, confusion or depression, myalgia and arthralgia, dry mouth, polydipsia, anorexia, constipation, abdominal pain, and, eventually, coma. An important first step in the treatment of hypercalcemia is to replenish fluids, since hypercalcemia increases filtration across the renal glomerular membrane, interferes with urine concentration, and causes diuresis and hypovolemia. Therefore, aggressive fluid resuscitation is necessary to reverse the hypovolemia and improve urinary calcium excretion. Additionally, diuretics and corticosteroids are often used to treat the hypercalcemia patient. Forced diuresis with loop diuretics can help avoid fluid overload and also increase urinary calcium absorption, and corticosteroids can both decrease calcium absorption from the gut and promote renal excretion. In severe cases and in patients with advanced myeloma-related kidney disease, hemodialysis may be necessary (8). Administration of anti-hypercalcemic medications is the next step. Calcitonin has a rapid onset of action and inhibits bone resorption without the risk of nephrotoxicity, but its ability to decrease calcium is modest and transient. Bisphosphonates (BPs), by contrast, are potent osteoclastic inhibitors with durable activity. These drugs are pirophosphate analogues in which the central oxygen bridge has been replaced by a carbon that is linked to different side chains. In first generation bisphosphonates, like clodronate, small radicals are linked to the carbon, while in second generation bisphosphonates nitrogen containing moieties, either simple (as in pamidronate) or more complex (as in zoledronic acid) are found (9). Bisphosphonates bind avidly to the bone mineral matrix and therefore accumulate in bone at sites of active bone metabolism. The most common bisphosphonates used for hypercalcemia in myeloma include zolendronic acid (Zometa) or pamidronate (Aredia) $(7,8)$. Dental procedures, such as root canal or extraction of teeth, may be associated with infection or destruction of the jaw (osteonecrosis), so they should be performed before bisphosphonate treatment is started.

\section{Spinal cord compression}

Skeletal related events are not uncommon in patients with multiple myeloma. Among these, the spine is one of the most commonly involved sites and pathological fractures of the spinal column are the most common spinal involvement of $\mathrm{MM}(9,10)$. Another form of spinal involvement is spinal cord compression. Spinal cord compression is reported to develop in $11-23 \%$ of patients with MM. Clinical features depend on the nature of the cord compression, the spinal level, extend of the disease and the rate of development of cord compression and commonly include sensory loss, paresthesiae, limb weakness, walking difficulty and sphincter disturbance (11). Most cord-compression lesions occur due to a pathological fracture of the involved vertebral body or extension of vertebral body myeloma lesion. However, an epidural myeloma could elicit spinal cord compression as a rare form of extra osseous myeloma. This is a very uncommon condition and is found in $<$ $5 \%$ of patients with MM (12). Radiographs in patients with an epidural myeloma are usually normal and in some cases, multiple compression fractures and osteopenic appearance of the vertebral body could suggest MM. MRI is the best diagnostic modality for detecting spinal cord compression, epidural masses and marrow involvement of MM. Extraosseus epidural myeloma is believed to originate from lymphoid tissue in the epidural or paraspinal lymph node. In general, extraosseus myeloma involvement at diagnosis or during the course of disease is considered a poor prognosis (9). Failure of neurological recovery has been observed in most reported cases with various treatment modalities (12, 13). No clear guidelines have been established for spinal cord compression caused by a myeloma. Some authors recommend radiotherapy combined with high-dose steroid therapy as the first choice of treatment because MM is highly sensitive to radiotherapy (14). In one report, radiotherapy alone was tried for 63 patients. The authors reported that $76 \%$ of the patients experienced an improvement in motor function, $2 \%$ deteriorated and local control was achieved in $98 \%$ in one year. In contrast, surgical decompression was attempted in several reports and early surgical decompression followed by radiotherapy or chemotherapy was recommended (15). However, the most authors agreed that timely intervention is critical for spinal cord compression by a myeloma. Neurological recovery beyond the critical point is extremely rare regardless of the radiotherapy or surgery attempted. Close observation of the neurological status and patient and medical staff awareness of neurological deterioration are also important to prevent neurological deficits and obtain favorable results. Moreover, the involved level by the epidural myeloma 
is one of the important factors to be considered. If the involved level is the cervical or thoracic level, more attentions should be paid to monitor the neurologic status. Surgical intervention prior to non-surgical treatment should be considered in the cases presented with any deterioration of the neurological status (16).

\section{Early infection}

It has been reported that up to $10 \%$ of patients with MM die of infective causes early, within 60 days of diagnosis. A variety of factors underlie the increased susceptibility of myeloma patients to infectious disease. The immune factors include hypogammaglobulinaemia, impaired lymphocyte function, steroid-related immunosuppression and neutropenia secondary to chemotherapy or marrow infiltration. Physical factors are also important, such as indwelling vascular catheters, impaired mucosal integrity and respiratory compromise because of a combination of pain, vertebral collapse and the use of opiate drugs. The risk of infection is highest in the first 3 months after diagnosis and decreases with response to treatment (17). A recent retrospective analysis of 3107 myeloma patients registered onto UK Medical Research Council (MRC) trials from 1980 to 2002 showed that $10 \%$ of patients died within 60 days of trial entry (18) and $45 \%$ of these deaths were caused by infection. Blade et al (2001)found in two studies that $7.9 \%$ of patients died within 2 months of diagnosis. Streptococcus pneumoniae, Haemophilus influenzae and Escherichia coli are the most frequent causes of infection in myeloma patients (19). Several studies in neutropenic patients suggest that prophylactic antibiotics, such as cotrimoxazole in a small randomized trial in myeloma (20) and levofloxacin in solid tumours (21), may have a role in reducing infection rates but have the potential for leading to antibiotic resistance in the community. Larger studies are required to address the role of prophylactic antibiotics, vaccination strategies and immunoglobulin replacement in multiple myeloma.

\section{Bone disease}

Bone lesions from multiple myeloma are the primary cause of bone pain, which is one of the most common symptoms of multiple myeloma. Bone lesions result in destruction of the bones in myeloma patients and primarily affecting the spine, pelvis or rib cage. In the majority of patients with myeloma, soft spots develop where the bone structure has been damaged. These can extend from the inner bone marrow to the outside surface of the bone. Soft spots appear as "holes" on a standard bone $\mathrm{x}$-ray and are referred to as osteolytic le- sions. These bone lesions weaken the bone, causing pain and increasing the risk of fractures. Bone loss frequently accompanies multiple myeloma, and $85 \%$ of patients diagnosed with multiple myeloma have some degree of bone loss (22). Bone destruction by osteolytic lesions is caused by two separate events. Rapid growth of myeloma cells inhibits normal bone-forming cells, damaging bone. In addition, production of substances that activate the cells that resorb bone, called osteoclasts, is increased. Osteoclasts normally break down old or worn out bone and work with bone-forming cells to repair bone. In the case of multiple myeloma, however, the increased activity of osteoclasts causes bone loss with concomitant loss of bone repair and growth from the suppression of bone formation (23). In patients with multiple myeloma, bone resorption by the osteoclasts is increased and exceeds bone reformation. Calcium lost from the bones appears in increasing amounts in the patient's serum and urine. This increase in bone resorption may result in pain, bone fractures, spinal cord compression, and hypercalcemia. Long bone fractures are treated by immobilization and radiotherapy that can improve pain and promote healing of the fracture site. The recommended dose is 8 Gy for a single fracture. In case of larger lytic lesions of skeleton, an orthopedic surgeon should be consulted and in some patients a surgery with vertebroplasty or kyphoplasty should be done. Bisphosphonates have a favorable effect in controlling the bone lesions in patients with MM, even in those without bone disease at presentation. The duration of the treatment depends on individual factors such as: achieving remission, expressiveness of bone lesions, renal function (24). It is reasonable to stop the treatment in patients who achieve complete response or a very good partial remission and who do not have active bone disease. It is mandatory to perform a good dental inspection always when bisphosphonate therapy is planned and to perform dental procedures such as root canal or extraction of teeth before these agents are started in order to prevent the most difficult complication-osteonecrosis of the jaw.

\section{Renal failure}

Renal failure is a frequent and potentially serious complication that occurs in $20-25 \%$ of patients with $\mathrm{MM}$ at presentation and in nearly $50 \%$ of patients during the disease course. In the majority of cases, renal impairment is caused by the accumulation and precipitation of light chains, which form casts in the distal tubules, resulting in renal obstruction. In addition, myeloma light chains are also directly toxic on proximal renal tubules, further adding to renal dysfunction (25). There are several types of apheresis therapy that 
are applicable in MM patients. Plasma exchange (PE) or plasmapheresis involves the separation and removal of the blood cells and other substances from the plasma by centrifugation (based on cell density) or ultrafiltration using large-pore hemofilters (based on molecular size) (26). This method is used to remove pathogenic substances, including paraproteins and inflammatory mediators such as cytokines.

Other factors such as dehidratation, hypercalcemia, hyperuricemia, application of nephrotoxic agents for infections, also, contribute to renal failure. Adequate hydration, correction of hypercalcemia and hyperuricemia and antimyeloma therapy should be initiated promptly. For maintenance of a good renal function, patients are advised to stay well-hydrated, to drink enough fluids to produce three liters of urine daily and to avoid nephrotoxic agents including aminoglycosides and non-steroidal anti-inflammatory drugs.

Patients, who have renal failure at presentation, have high level of early fatal outcomes. Supportive care measures are essential and antimyeloma therapy should be initiated as soon as possible. High-dose dexamethasone-based regimens remain the cornerstone in the treatment of these patients, owing to their rapid antimyeloma activity (27). Severe renal impairment and large amount of proteinuria are associated with a lower probability of renal recovery. The addition of novel agents can further increase the rapidity of response and perhaps the probability of restoring renal function.

\section{CONCLUSION}

Despite the discovery of novel anti-myeloma agents, multiple myeloma still remains an incurable di- sease for the vast majority of patients, with a median survival 2-3 years. The incidence of early death within 60 days of diagnosis is $10 \%$ due to many acute complications such as hyperviscosity syndrome, hypercalcemia, spinal cord compression, early infection, bone disease and renal impairment. The most common contributors are bacterial infection (50\%) and renal failure (28\%) according to the United Kingdom's Medical Research Council (MRC) trials. These complications require specific treatment in addition to therapy directed at the malignant clone that has greatly decreased morbidity and early mortality in patients.

\section{CONFLICT OF INTEREST}

The authors declare that there is no conflict of interest.

\section{Licensing}

This work is licensed under a Creative Commons Attribution 4.0 International (CC BY 4.0) License.

\section{Abbreviations}

CRAB - calcium elevation, renal insufficiency, anemia, bone disease

IgG - immunoglobulin $\mathrm{G}$

IgA - immunoglobulin A)

IgM - immunoglobulin M

MRI - magnetic resonance imaging

MM - myeloma multiplex

PE - plasma exchange

UK MRC - United Kingdom's Medical Research Council

\title{
Sažetak
}

\section{AKUTNE KOMPLIKACIJE MULTIPLOG MIJELOMA}

\author{
Stankovikj Svetlana, ${ }^{1}$ Martinova Kata ${ }^{2}$ \\ ${ }^{1}$ University Clinic of Hematology, Skopje, Macedonia \\ ${ }^{2}$ University Childrenžs Hospital, Skopje, Macedonia
}

Multipli mijelom je maligno oboljenje plazma ćelija, koje karakteriše nekontrolisana i progresivna proliferacija jednog klona plazma ćelije. Oboljenje vodi do progresivnog morbiditeta i eventualnog mortaliteta, tako što snižava otpor organizma na infekcije i dovodi do značajnih oštećenja na skeletu, praćenog bolom u kostima, patološkim frakturama i hiperkalcemijom. Bolje razumevanje biologije multiplog mijeloma zajedno sa otkrićem novih anti-mijelomskih agenasa dovelo je do boljeg lečenja bolesnika. Međutim, multipli mijelom je još uvek neizlečiva bolest za većinu pacijenata, sa sred- njom stopom preživljavanja 2-3 godine. Pacijenti koji boluju od multiplog mijeloma često razvijaju komplikacije, koje su razlog njihovog ranijeg mortaliteta u okviru prvih 60 dana od postavljanja dijagnoze. Akutne komplikacije kao što su hiperviskozni sindrom, hiperkalcemija, kompresija kičmene moždine, rana infekcija, oboljenja kostiju i bubrega mogu biti životno ugrožavajuća. Lečenje ovih urgentnih medicinskih stanja uveliko smanjuje morbiditet i rani mortalitet kod ovih bolesnika.

Ključne reči: multipli mijelom, hiperviskozni sindrom, hiperkalcemija, kompresija kičmene moždine. 


\section{REFERENCES}

1. Palumbo A, Anderson K. Multiple myeloma. N Engl J Med.2011; 364(11): 1046-60.

2. Ferlay J, Shin HR, Bray F, Forman D, Mathers C, Parkin DM. Estimates of worldwide burden of cancer in 2008: GLOBOCAN 2008. Int J Cancer 2010; 127(12): 2893- 917.

3. Mehta J, Singhah S. Hyperviscosity syndrome in plasma cell dyscrasias. Semin Thromb Hemost. 2003; 29(5): 467-71

4. Kwaan HC. Hyperviscosity in plasma cell dyscrasias. Clin Hemorheol Microcirc. 2013; 55 (1):75-83.

5. Patient Care Spotlight. Current Management of Hypercalcemia Associated with Multiple Myeloma. Advances in Hematologic Malignancies. 2013; Issue 2.

6. Stewart AF. Clinical practice. Hypercalcemia associated with cancer. N Engl J Med. 2005; 352(4): 373-9.

7. Durie BGM, Salmon SE, Mundy GR. Relation of osteoclast activating factor production to the extent of bone disease in multiple myeloma. Br J Haematol. 1981; 47(1): 21-30.

8. Thomas S.A, Chung S-H. Management of Hypercalcemia of Malignancy. JHOP, 2016; 6(1): 18-21.

9. Tosi P. Diagnosis and treatment of bone disease in multiple myeloma: spotlight on spinal involvement. Scientifica. 2013; 2013: 104546.

10. Damaj G, Mohty M, Vey N, Dincan E, Bouabdallah R, Faucher C, et al. Features of extramedullary and extraosseous multiple myeloma: a report of 19 patients from a single center. Eur J Haematol. 2004; 73(6): 402-6.

11. Benson WJ, Scarffe JH, Todd ID, Palmer M, Crowther D. Spinal-cord compression in myeloma. Br Med J. 1979; 1(6177): 1541-4.

12. Matsui H, Fujie H, Tsuji H. Extraosseous epidural tumor of immunoglobulin D myeloma. J Spinal Disord. 1992; 5(3): 366-9.

13. Avadhani A, Shetty AP, Rajasekaran S. Isolated extraosseous epidural myeloma presenting with thoracic compressive myelopathy. Spine J. 2010; 10(4): e7-e10.

14. Lourbopoulos A, Ioannidis P, Balogiannis I, Stavrinou P, Koletsa T, Karacostas D. Cervical epidural plasmacytoma presenting as ascending paraparesis. Spine J. 2011; 11(5): e1-4.

15. Jin R, Rock J, Jin JY, Janakiraman N, Kim JH, Movsas $\mathrm{B}$, et al. Single fraction spine radiosurgery for myeloma epidural spinal cord compression. J Exp Ther Oncol. 2009; 8(1): 35-41.
16. Renier JC, Brégeon C, Boasson M, Audran M, Emile J, Guy G, et al. Spinal cord compression in multiple myeloma Study of 10 cases. Rev Rhum Mal Osteoartic. 1984; 51(4): 193-6.

17. Smith A, Wisloff F, Samson D, UK Myeloma Forum, Nordic Myeloma Study Group, British Committee for Standards in Haematology.. Guidelines on diagnosis and management of multiple myeloma 2005. British Journal of Hematology 2006; 132(4): 410-51.

18. Augustson BM, Begum G, Dunn JA, Barth Nj, Davies F, Morgan $\mathrm{G}$ et al. Early mortality after diagnosis of multiple myeloma: analysis of patients entered onto the United kingdom Medical Research Council trials between 1980 and 2002-Medical Research Council Adult Leukaemia Working Party. J Clin Oncol. 2005; 23(36): 9219-26.

19. Savage DG, Lindenbaum J, Garret TJ. Biphasic pattern of bacterial infection in multiple myeloma. Ann Intern Med. 1982; 96(1): 47-50.

20. Oken MM, Pomeroy C, Weisdorf D, Bennett JM. Prophylactic antibiotics for the prevention of early infection in multiple myeloma. Am J Med. 1996; 100(6): 624-8.

21. Bucaneve G, Micozzi A, Menichetti F, Martino P, Dionisi MS, Martinelli G et al. Levofloxacin to prevent bacterial infection in patients with cancer and neutropenia. N Engl J Med. 2005; 353(10): 977-87.

22. Terpos E, Dimopolous M.A. Myeloma bone disease: pathophysiology and management. Ann Oncol. 2005; 16(8): 1223-31.

23. Giuliani N, Colla S, Rizzoli V. Update on the pathogenesis of osteolysis in multiple myeloma patients, Acta Biomed. 2004; 75(3): 143-52.

24. Barille-Nion S, Bataille R. New insights in myeloma-induced osteolysis. Leuk Lymphoma. 2003; 44(9): 1463-7.

25. Eleutherakis-Papaiakovou V, Bamia A, Gika D, Simeonidis A, Pouli A, Anagnostopoulos A, et al. Renal failure in myeloma multiplex: incidence, correlations and prognostic significance. Leukemia and Lymphoma. 2007; 48(2): 337-41.

26. Katagiri D, Noiri E, Hinoshita F. Multiple Myeloma and Kidney Disease. The Scientific World Journal. 2013; 2013 : 487285.

27. Dimopoulos MA, KastritisE, RosinolL, BladéJ, and LudwigH. Pathogenesis and treatment of renal failure in multiple myeloma. Leukemia. 2008; 22(8): 1485-93.

\author{
Correspondence to / Autor za korespondenciju \\ Svetlana Stankovikj \\ ul. Partenij Zografski, 111000 Skopje, Macedonia \\ Tel.: 38923147931 \\ Mob: 38978356034 \\ Fax: 38923147931 \\ E-mail: svetlanastankovic2002@yahoo.com
}

